\title{
Preparation of Magnetic Carbon Nanotubes with Hierarchical Copper Silicate Nanostructure for Efficient Adsorption and Removal of Hemoglobin
}

\author{
Min Zhang ${ }^{* \dagger}$, Yongtao Wang ${ }^{\dagger}$, Yanwei Zhang ${ }^{\dagger}$, Lei Ding ${ }^{\dagger}$, Jing Zheng ${ }^{\dagger}$, Jingli Xu* ${ }^{* \dagger}$ \\ ${ }^{\dagger}$ College of Chemistry and Chemical Engineering, Shanghai University of Engineering Science, \\ Shanghai 201620, China.
}

\begin{abstract}
The controllable synthesis of materials with the desired structure and dimensionality is of great significance in material science. In this work, the hierarchical $\mathrm{CNTs} / \mathrm{Fe}_{3} \mathrm{O}_{4} @$ copper silicate $\left(\mathrm{CNTs} / \mathrm{Fe}_{3} \mathrm{O}_{4} @ \mathrm{CuSilicate}\right)$ composites was synthesized via a simple chemical conversion route by using $\mathrm{CNTs} / \mathrm{Fe}_{3} \mathrm{O}_{4} @ \mathrm{SiO}_{2}$ nanocables as template. Firstly, magnetic CNTs composites $\left(\mathrm{CNTs} / \mathrm{Fe}_{3} \mathrm{O}_{4}\right)$ were synthesized by the high temperature decomposition process using the iron acetylacetonate as raw materials. Then a layer of $\mathrm{SiO}_{2}$ can be easily coated on the magnetic CNTs by the stöber method, which were then converted into $\mathrm{CNTs} / \mathrm{Fe}_{3} \mathrm{O}_{4} @ \mathrm{CuSilicate}$ composites by hydrothermal reaction between the silica shell and copper ions in alkaline solution. The resulting CNTs/ $\mathrm{Fe}_{3} \mathrm{O}_{4} @ \mathrm{CuSilicate}$ composites hold merits such as magnetic responsivity, good dispersibility, and large specific surface area. Moreover, the $\mathrm{CNTs} / \mathrm{Fe}_{3} \mathrm{O}_{4} @$ copper silicate composites have strong affinity toward bovine hemoglobin(BHb), which were successfully applied to convenient, efficient, and fast removal of abundant proteins(HHb and HSA) in human blood.
\end{abstract}

\section{Introduction}

With the increasing need for purified proteins in applications ranging from diagnostics to therapeutics, the development of efficient methods for the separation and purification of recombinant proteins has aroused great interest in proteomics [1]. Currently, immobilized metal affinity chromatography (IMAC) is the most frequently

* Corresponding auther:E-mail address: congmingyang123@163.com, (M Zhang)

*xujingli@sues.edu.cn, (JL Xu) 
used method for the separation of His-tagged proteins from a matrix containing other undesirable biological elements[2, 3]. However, this technique has limitations including the need for pre-treatment on removing the cell debris and fouling components. In order to circumvent these limitations, several separation systems based on magnetic nanomaterials have been developed, such as nitrilotriacetic acid (NTA)[4] or polymer brush-modified magnetic nanoparticles[5], $\mathrm{Au}-\mathrm{Ni}-\mathrm{Au}$ triblock nanorods[6], $\mathrm{Ni} / \mathrm{NiO}$ core-shell nanoparticles[7], $\mathrm{Fe}_{2} \mathrm{O}_{3} / \mathrm{SiO}_{2}$ core-shell microspheres decorated with $\mathrm{NiO}$ nanoparticles[8]. However, these systems, still suffer from drawbacks such as complicated synthesis procedures, limited surface area as well as low metal ion intensity. Therefore, it is necessary to develop new approaches to fabricate magnetic materials for proteins with appropriate magnetic properties.

To overcome these problems, the well-designed hierarchical magnetic metal silicate nanomaterials have emerged as powerful candidates for meeting the above mentioned requirements. Metal silicates have attracted significant interest due to exhibit much higher stability in various chemical and physical environments, and they are widely used in adsorption, separation, and catalytic fields[9,10]. The hierarchical metal silicate architectures assembled from nanoscale units can avoid aggregation while maintaining high metal ion density, which greatly favors enhancing protein binding capacity. For example, Liu etc have synthesized $\mathrm{Fe}_{3} \mathrm{O}_{4} @ \mathrm{NixSiOy}$, which provides a convenient means of purifying His-tagged proteins[11]. Wang etc have fabricated the yolk-shell nanostructured $\mathrm{Fe}_{3} \mathrm{O}_{4} @ \mathrm{NiSiO}_{3}$ by a facile sol-gel and hydrothermal method. The outer shell of nickel silicate could provide for a selective adsorption of His-tagged protein from the mixed-protein solutions[12]. However, these works are only limited to the zero materials(spheres). Compared to metal silicate nanospheres, one-dimensional metal silicate nanomaterials have better mechanical strength, higher specific surface areas and shorter diffusion path for mass transportation, and are thereby more suitable for adsorption. Thus, synthesizing such one-dimensional metal silicate nanomaterials has been highly desired. Song and his co-workers have 
synthesized hierarchical double-walled copper/nickel/magnesium silicate hollow nanofibers and their application as an efficient and reusable adsorbents for the removal of dye[13-15]. More recently, Song etc have designed a magnetic magnesium silicate nanotubes by a well-controlled programmed synthesis, and they showed very good adsorption properties for $\mathrm{Pb}(\mathrm{II})$ and $\mathrm{Cd}(\mathrm{II})[16]$. Although great progress has been achieved in removing the hazardous substances, few reports were reported to adsorb and separate the proteins using the one dimensional metal silicate materials. Furthermore, combining the one dimensional metal silicate materials with magnetism may help for protein separation with the external magnetic field.

In this regards, the hierarchical $\mathrm{CNTs} / \mathrm{Fe}_{3} \mathrm{O}_{4} @$ copper silicate composite was synthesized via a simple in situ chemical conversion route by using $\mathrm{CNTs} / \mathrm{Fe}_{3} \mathrm{O}_{4} @ \mathrm{SiO}_{2}$ nanocable as template. Owing to the high copper density on the surface and the response toward an assistant magnet, these materials could be applied to selectively bind and magnetically separate $\mathrm{HHb}$ and HSA from diluted human blood. To the best of our knowledge, this kind of magnetic one-dimensional hierarchical copper silicate structure has not been reported before. When used as protein adsorbent, the hierarchical $\mathrm{CNTs}_{2} / \mathrm{Fe}_{3} \mathrm{O}_{4} @$ copper silicate (CNTs/ $\left./ \mathrm{Fe}_{3} \mathrm{O}_{4} @ \mathrm{CuSilicate}\right)$ composite exhibited excellent protein adsorption capability.

\section{Experimental Section}

\subsection{Chemicals}

Multiwalled CNTs (MWCNTs) with a mean diameter of 60-100 nm were provided by the Shenzhen Nanotech Port Co. Ltd. Iron(III) acetylacetonate (Fe(acac) 3 , 99\%) was purchased from Acros. Triethylene glycol (TREG, 99\%) was from Aldrich. Tetraethoxysilane (TEOS, 95\%) was obtained from the Alfa Aesar Chemical Company, which was used directly without further purification. Copper chloride hydrate $\left(\mathrm{CuCl}_{2} \cdot 2 \mathrm{H}_{2} \mathrm{O}\right)$, ammonia solution (28-30\%), water and ethanol were used for 
all experiments. Other chemical reagent were purchased from shanghai chemical reagent company.

\subsection{Synthesis of $\mathrm{CNTs} / \mathrm{Fe}_{3} \mathrm{O}_{4}$ composites:}

$\mathrm{CNTs} / \mathrm{Fe}_{3} \mathrm{O}_{4}$ composites were fabricated according to the literature with minor modification [15]. In a typical procedure, $400 \mathrm{mg} \mathrm{Fe}(\mathrm{acac})_{3}$ and $100 \mathrm{mg}$ MWCNTs were added to $60 \mathrm{~mL}$ TREG and ultrasonicated for $10 \mathrm{~min}$. The resulting mixture was then heated to $278{ }^{\circ} \mathrm{C}$ under $\mathrm{N}_{2}$ protection and kept at reflux for $30 \mathrm{~min}$. After cooling to room temperature, the obtained composites were magnetically separated by a magnet and washed with ethanol for several times and dried at $60{ }^{\circ} \mathrm{C}$ in vacuum.

\subsection{Synthesis of $\mathrm{CNTS} / \mathrm{Fe}_{3} \mathrm{O}_{4} @ \mathrm{SiO}_{2}$ composites:}

The synthesis procedure is based on the stöber method. In a typical procedure, $30 \mathrm{mg}$ $\mathrm{CNTs} / \mathrm{Fe}_{3} \mathrm{O}_{4}$ composites were added to $250 \mathrm{~mL}$ three-neck round flask containing 95 $\mathrm{mL}$ ethanol and $5 \mathrm{~mL}$ water. The mixture was sonicated for $50 \mathrm{~min}$. Then $0.5 \mathrm{~mL}$ TEOS was slowly added to the above solution in 30 min under mechanical stirring. After kept stirring for $6 \mathrm{~h}$, the precipitates were separated by a magnet and washed with ethanol and water for 5 times and dried at $60{ }^{\circ} \mathrm{C}$ in vacuum.

\subsection{Synthesis of CNTs/Fe $\mathrm{F}_{3} @ \mathrm{CuSilicate}$ composites :}

In a typical procedure, $50 \mathrm{mg} \mathrm{CNTs} / \mathrm{Fe}_{3} \mathrm{O}_{4} @ \mathrm{SiO}_{2}$ nanotubes, $1 \mathrm{mmol} \mathrm{CuCl}_{2} \cdot \mathrm{H}_{2} \mathrm{O}, 10$ mmol $\mathrm{NH}_{4} \mathrm{Cl}$ and $1 \mathrm{~mL} \mathrm{NH} \cdot \mathrm{H}_{2} \mathrm{O}(28 \%)$ were dissolved in $40 \mathrm{ml}$ DI water and ultrasonicated for $10 \mathrm{~min}$, and then the reaction solution was poured into a Teflon-lined autoclave with volume of $50 \mathrm{~mL}$. The oven was heated to $140{ }^{\circ} \mathrm{C}$ and kept at that temperature for $12 \mathrm{~h}$. After cooling to room temperature, precipitates were collected as $\mathrm{CNTs} / \mathrm{Fe}_{3} \mathrm{O}_{4} @ \mathrm{CuSilicate}$ by centrifugation and washed with ethanol for five times, and then dried at $60{ }^{\circ} \mathrm{C}$ for $3 \mathrm{~h}$.

\subsection{Instrumentation}

The data of UV-vis adsorption were obtained by using UV-2450 spectrophotometer (Shimadzu, Japan). The crystal structure of nanoparticles was determined by X-ray diffractometer (XRD). The XRD pattern of each sample was recorded with a 
Shimadzu (Japan) D/Max-2500 diffractometer, using a monochromatized X-ray beam with nickel-filtered $\mathrm{Cu}=\mathrm{K} \alpha$ radiation. The XRD patterns were collected in the range of $5^{\circ}<2 \theta<80^{\circ}$ with a dwelling time of $2 \mathrm{~s}$ and a scan rate of $6.0^{\circ} / \mathrm{min}$. The substance is automatically searched by using JCPDS-International Center for Diffraction Data. The morphology and microstructures of the samples were characterized by scanning electron microscopy (SEM, JEOL-4800), transmission electron microscopy (TEM, JEOL-1011) and high-resolution transmission electron microscopy (HR-TEM) (FEI Tecnai T200). The nitrogen adsorption-desorption isotherms were measured on a Quantachrome Autosorb AS-1 instrument. The magnetic properties were collected using vibrating sample magnetometry (VSM, MicroSense EV7) at room temperature. XPS of the Copper silicate state was measured using Physical Electronics PHI 5600 XPS spectrophotometer with monochromatic Al K (1486.6 eV) excitation source.

\section{Results and Discussion}

The fabrication process for $\mathrm{CNTs} / \mathrm{Fe}_{3} \mathrm{O}_{4} @ \mathrm{CuSilicate}$ is depicted in Scheme 1. Magnetite nanoparticles/carbon nanotubes (denoted as $\mathrm{CNT} / \mathrm{Fe}_{3} \mathrm{O}_{4}$ ) composites were firstly fabricated in one-pot procedure through a solvothermal method[17]. A thin layer of $\mathrm{SiO}_{2}$ was then coated onto the $\mathrm{CNT} / \mathrm{Fe}_{3} \mathrm{O}_{4}$ to produce $\mathrm{CNT} / \mathrm{Fe}_{3} \mathrm{O}_{4} @ \mathrm{SiO}_{2}$ nanocable, which were then converted into the hierarchical CNTs/ $/ \mathrm{Fe}_{3} \mathrm{O}_{4} @ \mathrm{CuSilicate}$ composites by hydrothermal reaction between the silica shell and copper ions in alkaline solution.
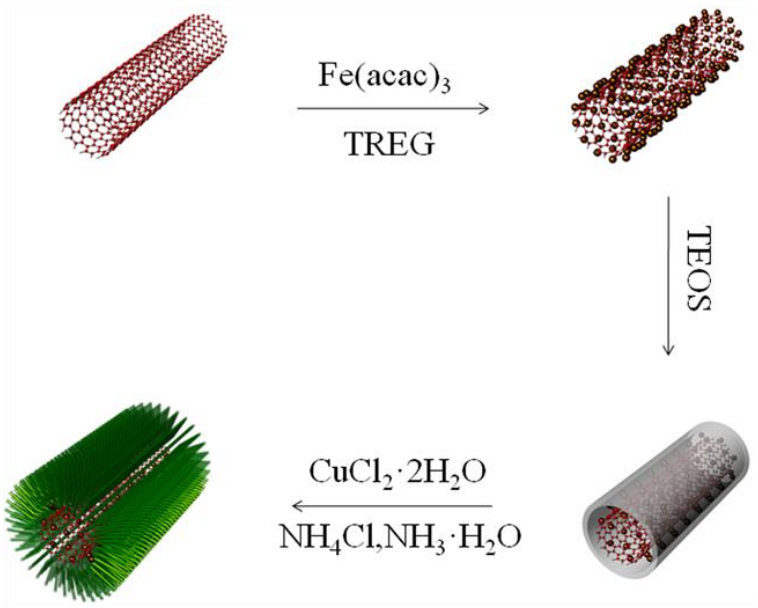
Scheme 1. Schematic illustration of synthesis of hierarchical structured CNTs/Fe $3 \mathrm{O}_{4} @ \mathrm{CuSilicate}$ composites

The morphologies and structural features of the prepared materials can be observed from the SEM and TEM images (Fig. 1). $\mathrm{Fe}_{3} \mathrm{O}_{4}$ nanoparticles with an average diameter of $8 \mathrm{~nm}$ were uniformly distributed on the surface of the CNTs. Functionalizing the assembled nanostructures stabilizing with a layer of hydrophilic polyol molecules, these $\mathrm{CNTs} / \mathrm{Fe}_{3} \mathrm{O}_{4}$ nanocomposites are highly water-dispersed, which is beneficial for $\mathrm{SiO}_{2}$ coating[18]. Using tetra-ethoxysilane (TEOS) as the silica source, a $\mathrm{SiO}_{2}$ layer was successfully coated on the $\mathrm{CNT} / \mathrm{Fe}_{3} \mathrm{O}_{4}$ nanocomposites. As shown in Fig. 1(d-f), and a $\mathrm{SiO}_{2}$ layer with thickness of $31 \mathrm{~nm}$ was coated on the $\mathrm{CNT} / \mathrm{Fe}_{3} \mathrm{O}_{4}$ nanocomposites . When the amount of TEOS was increased from $300 \mathrm{uL}$ to $500 \mathrm{uL}$, the thickness of silica layer for the $\mathrm{CNT} / \mathrm{Fe}_{3} \mathrm{O}_{4} @ \mathrm{SiO}_{2}$ nanocomposites can be increased to $50 \mathrm{~nm}$ (Fig. 1(g-i)). From which it can be confirmed that the thickness of the silica layer can be readily controlled by changing the TEOS amount. It can be seen that the surface of $\mathrm{CNT} / \mathrm{Fe}_{3} \mathrm{O}_{4} @ \mathrm{SiO}_{2}$ nanocomposites exhibit smoother than that of the $\mathrm{CNT} / \mathrm{Fe}_{3} \mathrm{O}_{4}$ nanocomposites, which fully prove that the successful deposition and growth of the silica layer on the $\mathrm{CNT} / \mathrm{Fe}_{3} \mathrm{O}_{4}$ composites. Additionally, no aggregates of the silica spheres are visible in the FSEM and TEM images. These results suggest that the $\mathrm{CNT} / \mathrm{Fe}_{3} \mathrm{O}_{4} @ \mathrm{SiO}_{2}$ nanocomposites were successfully synthesized. 


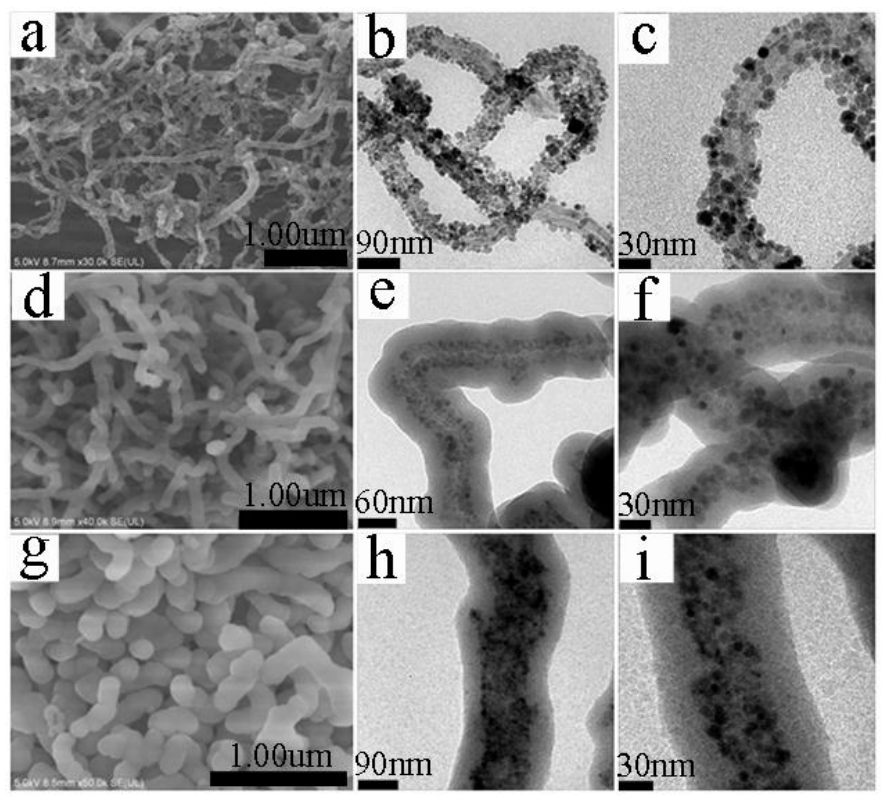

Fig. 1 SEM images of $\mathrm{CNTs} / \mathrm{Fe}_{3} \mathrm{O}_{4}$ (a), TEM images of $\mathrm{CNTs} / \mathrm{Fe}_{3} \mathrm{O}_{4}(\mathrm{~b}, \mathrm{c})$; SEM images of $\mathrm{CNTs} / \mathrm{Fe}_{3} \mathrm{O}_{4} @ \mathrm{SiO}_{2}(0.3 \mathrm{~mL}$ TEOS, (d)), TEM images of $\mathrm{CNTs} / \mathrm{Fe}_{3} \mathrm{O}_{4} @ \mathrm{SiO}_{2}\left(0.3 \mathrm{~mL}\right.$ TEOS, (e,f)); SEM images of CNTs/Fe $3 \mathrm{O}_{4} @ \mathrm{SiO}_{2}(0.5 \mathrm{~mL}$ TEOS, (g)), TEM images of $\mathrm{CNTs} / \mathrm{Fe}_{3} \mathrm{O}_{4} @ \mathrm{SiO}_{2}(0.5 \mathrm{~mL}$ TEOS, (h, i)).

Hydrothermal reaction with $\mathrm{CuCl}_{2}$ and $\mathrm{NH}_{3} \mathrm{H}_{2} \mathrm{O}$ is driven by the interfacial reaction between $\mathrm{Cu}^{2+}$ ions and the silicate anions, CuSilicate nanograins are grown readily around the surface of the $\mathrm{SiO}_{2}$ layer to form the CuSilicate shell[19-22]. Herein, the $\mathrm{SiO}_{2}$ layer serves not only as the precursor for the CuSilicate shell but also as a protector for the $\mathrm{CNT} / \mathrm{Fe}_{3} \mathrm{O}_{4}$. After the hydrothermal reaction, a single nanocomposites composed of many nanotubes can be clearly observed (Fig. 2). Most of the nanotubes stand on the surface of the nanocomposites and the mean diameter of the nanotubes is about $2 \mathrm{~nm}$ with a narrow size distribution. Many holes can be seen on the shell surface due to the open ends of the nanotubes, which endowed the $\mathrm{CNT} / \mathrm{Fe}_{3} \mathrm{O}_{4} @ \mathrm{CuSilicate}$ composites with more BET surface, this will be verified by the following BET test. In addition, the thicknesses of the copper silicate shells of these $\mathrm{CNT} / \mathrm{Fe}_{3} \mathrm{O}_{4} @ \mathrm{CuSilicate}$ core-shell nanocomposites can be readily tuned by the $\mathrm{SiO}_{2}$ layer thickness of the $\mathrm{CNT} / \mathrm{Fe}_{3} \mathrm{O}_{4} @ \mathrm{SiO}_{2}$ in the hydrothermal reaction. From the SEM and TEM imagine of Fig. 2, it can be observed that the copper silicate shells of the $\mathrm{CNT} / \mathrm{Fe}_{3} \mathrm{O}_{4} @ \mathrm{CuSilicate}$ composites are mainly dependent on the $\mathrm{SiO}_{2}$ layer 
thicknesses of the $\mathrm{CNT} / \mathrm{Fe}_{3} \mathrm{O}_{4} @ \mathrm{SiO}_{2}$ templates. Fig. 2(b, c) shows the TEM image of the CNT/ $\mathrm{Fe}_{3} \mathrm{O}_{4} @ \mathrm{CuSilicate}$ using the $\mathrm{CNT} / \mathrm{Fe}_{3} \mathrm{O}_{4} @ \mathrm{SiO}_{2}$ with $30 \mathrm{~nm} \mathrm{SiO}_{2}$ layer thickness as templates. It can be seen that the thickness of the copper silicate shells for the resulting nanocable is $\sim 60 \mathrm{~nm}$. When using the $\mathrm{CNT} / \mathrm{Fe}_{3} \mathrm{O}_{4} @ \mathrm{SiO}_{2}$ with $\sim 60 \mathrm{~nm}$ $\mathrm{SiO}_{2}$ layer thickness and keeping other experimental parameters fixed, the shell thickness of the copper silicate shell was increased to $\sim 100 \mathrm{~nm}$. These results are also in accordance with previous work [23].

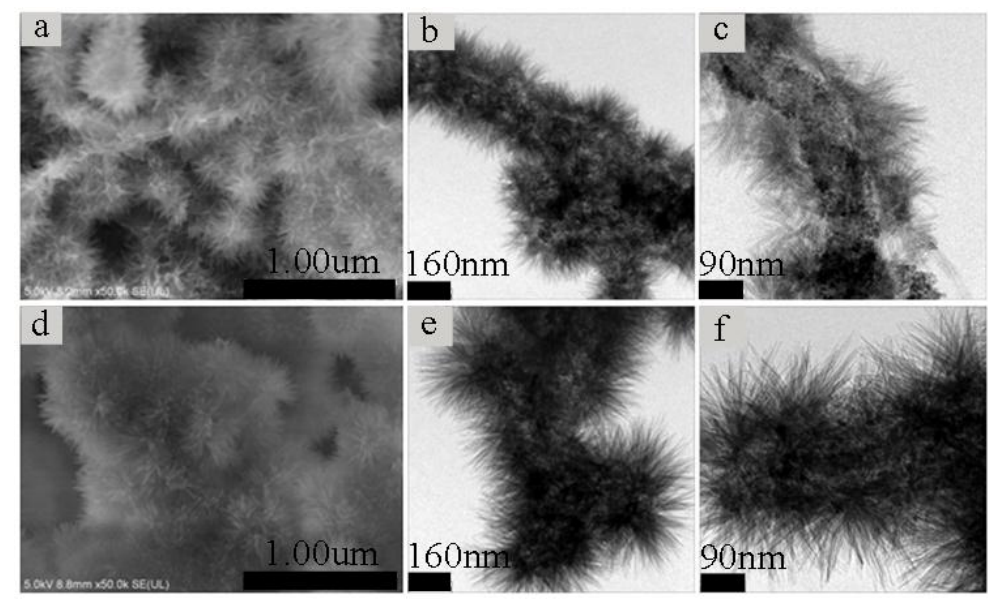

Fig. 2 SEM images of CNTs/Fe $\mathrm{O}_{4} @ \mathrm{CuSilicate}(0.3 \mathrm{mLTEOS}$; a), TEM images of CNTs/Fe $\mathrm{O}_{4} @ \mathrm{CuSilicate}(0.3 \mathrm{~mL} \quad \mathrm{TEOS}, \quad(\mathrm{b}, \quad \mathrm{c})), \quad$ SEM images of $\mathrm{CNTs} / \mathrm{Fe}_{3} \mathrm{O}_{4} @ \mathrm{CuSilicate} \quad(0.5 \mathrm{~mL} \quad \mathrm{TEOS}, \quad(\mathrm{d})), \quad$ TEM images of $\mathrm{CNTs} / \mathrm{Fe}_{3} \mathrm{O}_{4} @ \mathrm{CuSilicate}(0.5 \mathrm{~mL}$ TEOS, (e, f)).

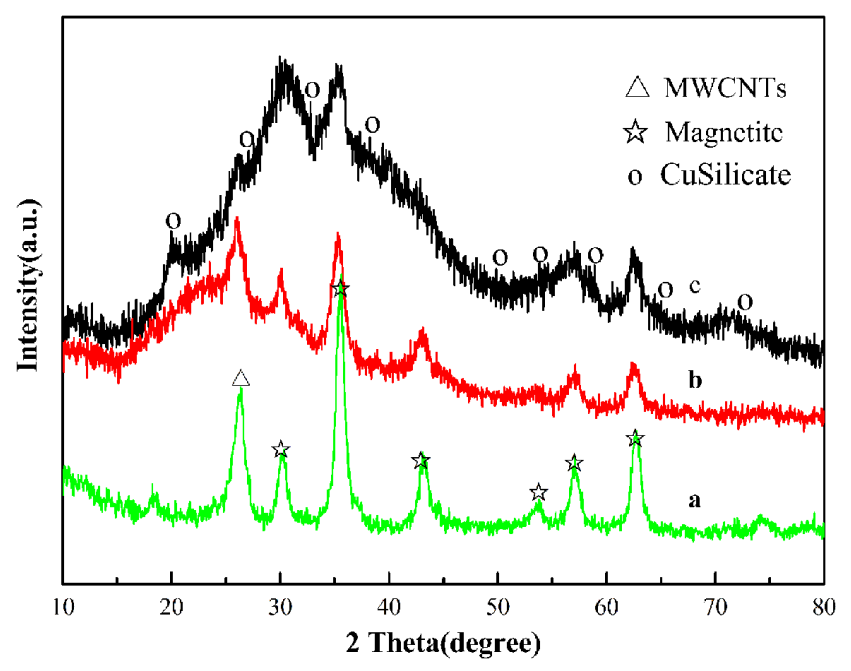

Fig. 3 XRD diffraction patterns of the as-prepared $\mathrm{CNTs} / \mathrm{Fe}_{3} \mathrm{O}_{4}(\mathrm{a})$, $\mathrm{CNTs} / \mathrm{Fe}_{3} \mathrm{O}_{4} @ \mathrm{SiO}_{2}(\mathrm{~b})$, and $\mathrm{CNTs} / \mathrm{Fe}_{3} \mathrm{O}_{4} @ \mathrm{CuSilicate}(\mathrm{c})$. 
The XRD patterns of the as-synthesized $\mathrm{CNTs} / \mathrm{Fe}_{3} \mathrm{O}_{4}, \mathrm{CNTs} / \mathrm{Fe}_{3} \mathrm{O}_{4} @ \mathrm{SiO}_{2}$ and $\mathrm{CNTs} / \mathrm{Fe}_{3} \mathrm{O}_{4} @ \mathrm{CuSilicate}$ are shown in Fig. 3. Fig. 3a shows the XRD pattern of the $\mathrm{CNTs} / \mathrm{Fe}_{3} \mathrm{O}_{4}$ particles, the diffraction peaks of as-received $\mathrm{Fe}_{3} \mathrm{O}_{4}$ at $30.00^{\circ}, 35.48^{\circ}$, $43.14^{\circ}, 53.44^{\circ}, 57.04^{\circ}$, and $62.58^{\circ}$ were observed. The positions and relative intensities of these CNTs $/ \mathrm{Fe}_{3} \mathrm{O}_{4}$ related new peaks match well with the (220), (311), (400), (422), (511), and (440) planes of the standard XRD data for the cubic spinel crystal structure of bulk magnetite. The diffraction peaks of MWCNTs at $25.98^{\circ}$ and $42.78^{\circ}$ could be attributed to the graphite structure (002) and (100) planes of the MWNTs[24]. As calculated by Scherrer's formula, the average crystallite size of the magnetite crystals was about $8 \mathrm{~nm}$. For the XRD spectrum of $\mathrm{CNTs} / \mathrm{Fe}_{3} \mathrm{O}_{4} @ \mathrm{SiO}_{2}$ (Fig. 3b), the major peaks are similar to the pristine $\mathrm{CNTs} / \mathrm{Fe}_{3} \mathrm{O}_{4}$ particles (Fig. 2a), revealing that the core-shell composites consist of the $\mathrm{CNTs} / \mathrm{Fe}_{3} \mathrm{O}_{4}$ component, and the obvious broad peaks at $22^{\circ}$ for the $\mathrm{SiO}_{2}$ is observed, indicating the $\mathrm{SiO}_{2}$ layer is amorphous. Fig. 3c shows the XRD pattern of the $\mathrm{CNTs} / \mathrm{Fe}_{3} \mathrm{O}_{4} @ \mathrm{CuSilicate}$ composite in which the diffraction peaks assigned to the magnetite can be clearly visible. All weak diffraction peaks of XRD pattern can be clearly indexed to copper silicate (JCPDS card no. 32-0346). It confirms the formation of magnetite-copper silicate composites. The apparent broadening and overlapping of all these peaks indicated that the as-prepared copper silicates were composed of nanoscale crystals.
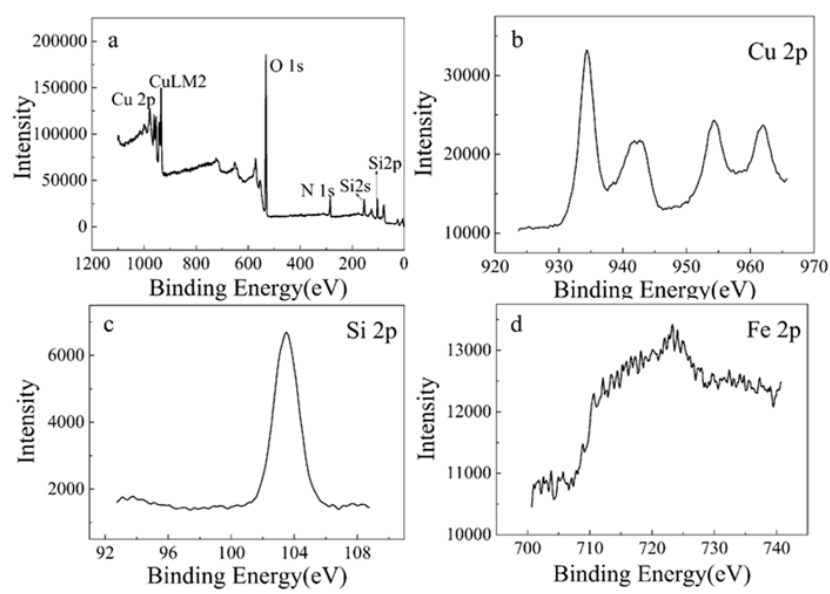

Fig. 4 XPS pattern of the $\mathrm{CNTs} / \mathrm{Fe}_{3} \mathrm{O}_{4} @ \mathrm{CuSilicate}$ composite. 


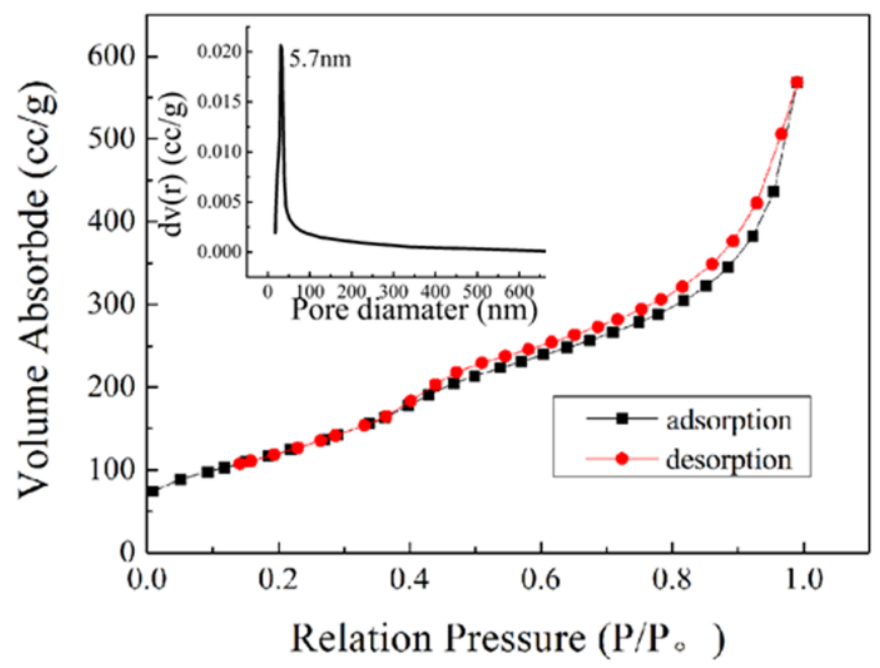

Fig. $5 \mathrm{~N}_{2}$ adsorption-desorption isotherms of $\mathrm{CNTs} / \mathrm{Fe}_{3} \mathrm{O}_{4} @ \mathrm{CuSilicate}$ composites.

Inset: pore size distributions.

X-ray photoelectron spectroscopy (XPS) (Fig. 4) was performed to analyze the chemical and oxidation states of the $\mathrm{CNTs} / \mathrm{Fe}_{3} \mathrm{O}_{4} @ \mathrm{CuSilicate}$ composites. All peaks on XPS curve for the composites are ascribed to $\mathrm{Cu}, \mathrm{Si}, \mathrm{O}, \mathrm{N}$ and $\mathrm{C}$. No other peaks can be observed. The peaks at 934.3 and $955.2 \mathrm{eV}$ can be addressed to the binding energy of $\mathrm{Cu} 2 \mathrm{p} 3 / 2$ and $\mathrm{Cu} 2 \mathrm{p} 1 / 2$, respectively, which fully indicates that copper ion was existed in the final product [25]. As shown in Fig. 4c, the peaks of Si 2s and Si 2p could be observed, and the binding energy of Si 2 p was $102.8 \mathrm{eV}$, which suggested that all samples were silicates rather than composites of $\mathrm{SiO}_{2}$, because the binding energies of $\mathrm{Si} 2 \mathrm{p}$ in many silicates are $102 \sim 103 \mathrm{eV}$ whereas that of the $\mathrm{SiO}_{2}$ is higher(103.8 eV) [26]. The binding energies of Fe 2p1/2 and Fe 2p3/2 (Fig. 4d) were not found to be 723.9 and $710.4 \mathrm{eV}$, respectively, because the $\mathrm{CNTs} / \mathrm{Fe}_{3} \mathrm{O}_{4}$ cores are coated with a shell thickness of CuSilicate layer above $10 \mathrm{~nm}$. X-ray photoelectron spectroscopy (XPS) allows the characterization of surface composition with a detection depth limit of approximately $10 \mathrm{~nm}[27,28]$. Therefore, if the shell thickness exceeds this value, any encapsulated cargo will not be detected. The nitrogen adsorption-desorption isotherms (Fig. 5) at $77 \mathrm{~K}$ of the $\mathrm{CNTs} / \mathrm{Fe}_{3} \mathrm{O}_{4} @ \mathrm{CuSilicate}$ composites show type IV curves, suggesting cylindrical pores with narrow pore size distribution at $5.7 \mathrm{~nm}$ (Fig. 5 Inset)[29]. The Brunauer-Emmett-Teller (BET) surface 
area and total pore volume were calculated to be about $453.2 \mathrm{~m}^{2} / \mathrm{g}$ and $0.65 \mathrm{~cm}^{3} / \mathrm{g}$, respectively, due to the mesoporous and hollow structures.

Fig. 6 shows the hysteresis loop of typical magnetic $\mathrm{CNTs} / \mathrm{Fe}_{3} \mathrm{O}_{4} @ \mathrm{CuSilicate}$ with different thickness of CuSilicate layer composites measured by sweeping the external field at room temperature. No obvious remanence or coercivity is observed in the magnetization curve at room temperature, suggesting a superparamagnetic character. The saturation magnetization of $\mathrm{CNTs} / \mathrm{Fe}_{3} \mathrm{O}_{4} @ \mathrm{CuSilicate}(100 \mathrm{~nm}$ and $60 \mathrm{~nm})$ are approximately $2.8,4 \mathrm{emug}^{-1}$ respectively, and this fully illustrates the thickness of the metal silicate layers makes a difference on the magnetic properties of composites. Inset shows the corresponding magnified hysteresis loops at low applied magnetic fields. The obvious magnetic hysteresis loops $(\mathrm{Hc}<30 \mathrm{Oe})$ were observed for the magnetic $\mathrm{CNTs} / \mathrm{Fe}_{3} \mathrm{O}_{4} @ \mathrm{CuSilicate}$ composites based on the field dependent magnetization plots in the inset of Fig. 6, which indicates that the products possessed superparamagnetic features at room temperature. Therefore, based on the combined VSM and above TEM, XRD, XPS results, the hierarchical copper silicate shell and superparamagnetic $\mathrm{CNTs} / \mathrm{Fe}_{3} \mathrm{O}_{4}$ cores were successfully prepared, which can be easily separated from the reaction solution by applying an external magnetic field.

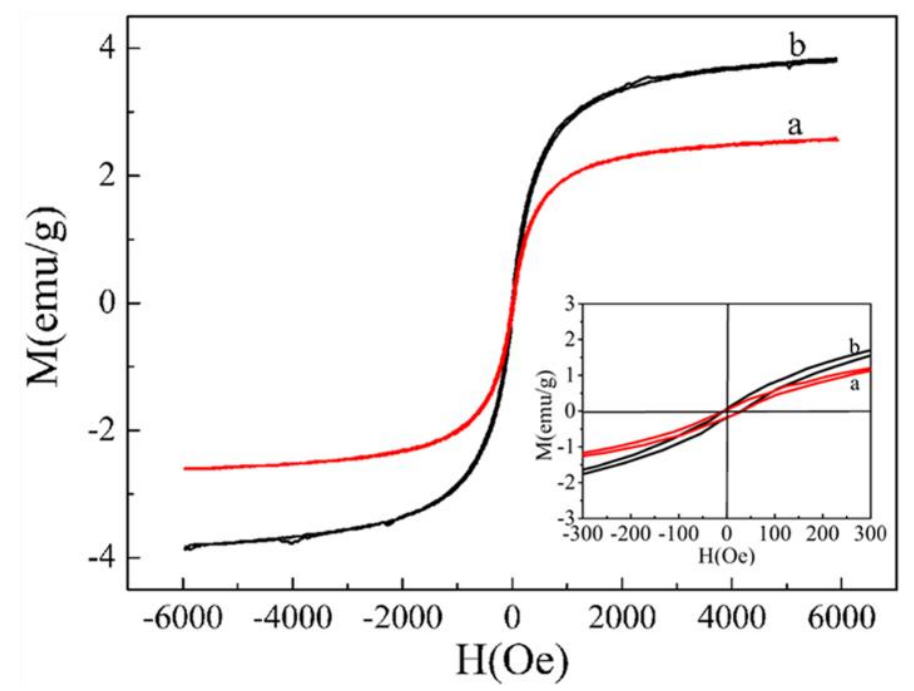

Fig. 6 Hysteresis loops of the magnetic $\mathrm{CNTs} / \mathrm{Fe}_{3} \mathrm{O}_{4} @ \mathrm{CuSilicate}$ composites, TEOS $0.3 \mathrm{~mL}(\mathrm{a})$, TEOS $0.5 \mathrm{~mL}$ (b) 
The $\mathrm{CNTs} / \mathrm{Fe}_{3} \mathrm{O}_{4} @ \mathrm{CuSilicate}$ composites were tested for the adsorption of $\mathrm{BHb}$ in $20 \mathrm{mM}$ phosphate buffer ( $\mathrm{pH}$ 8.0) by the batch experiment. Firstly, $1 \mathrm{mg}$ of $\mathrm{CNTs} / \mathrm{Fe}_{3} \mathrm{O}_{4} @ \mathrm{CuSilicate}$ was mixed with $5 \mathrm{~mL}$ of various concentrations of $\mathrm{BHb}$ solution $\left(0.02-0.1 \mathrm{mg} \mathrm{mL} \mathrm{m}^{-1}\right)$. Then, the mixture was shaken at $25^{\circ} \mathrm{C}$ for $12 \mathrm{~h}$, sufficient time to reach adsorption equilibrium. Analysis of Fig. 7 reveals that the $\mathrm{BHb}$ was effectively adsorbed. The $\mathrm{BHb}$ adsorption isotherm could be described by the Langmuir equation, Equation :

$$
q=\frac{q_{m} c}{K_{d}+c}
$$

where $c\left(\mathrm{mg} \mathrm{mL}^{-1}\right)$ and $q\left(\mathrm{mg} \mathrm{g}^{-1}\right)$ are the aqueous protein concentration and the amount of adsorbed protein at equilibrium, respectively. $q_{\mathrm{m}}\left(\mathrm{mg} \mathrm{g}^{-1}\right)$ is the maximum adsorption capacity and $K_{\mathrm{d}}\left(\mathrm{mg} \mathrm{mL}^{-1}\right)$ is the dissociation constant. By fitting the experimental data to the Langmuir equation, $q_{\mathrm{m}}$ and $K_{\mathrm{d}}$ are estimated to be $302.3 \mathrm{mg}$ $\mathrm{g}^{-1}$ and $0.20 \mathrm{mg} \mathrm{mL}^{-1}$ respectively.

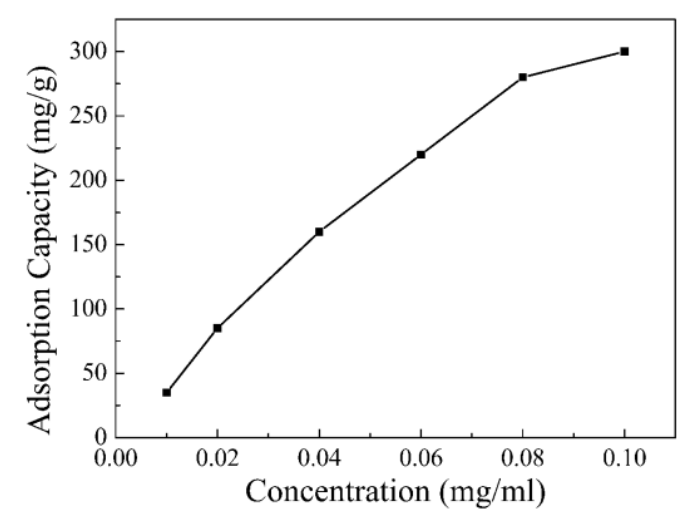

Fig. 7 Adsorption isotherm of $\mathrm{BHb}$ on $\mathrm{CNTs} / \mathrm{Fe}_{3} \mathrm{O}_{4} @ \mathrm{CuSilicate}$ in the solution containing $20 \mathrm{mM}$ phosphate at $\mathrm{pH}$ 8.0. 

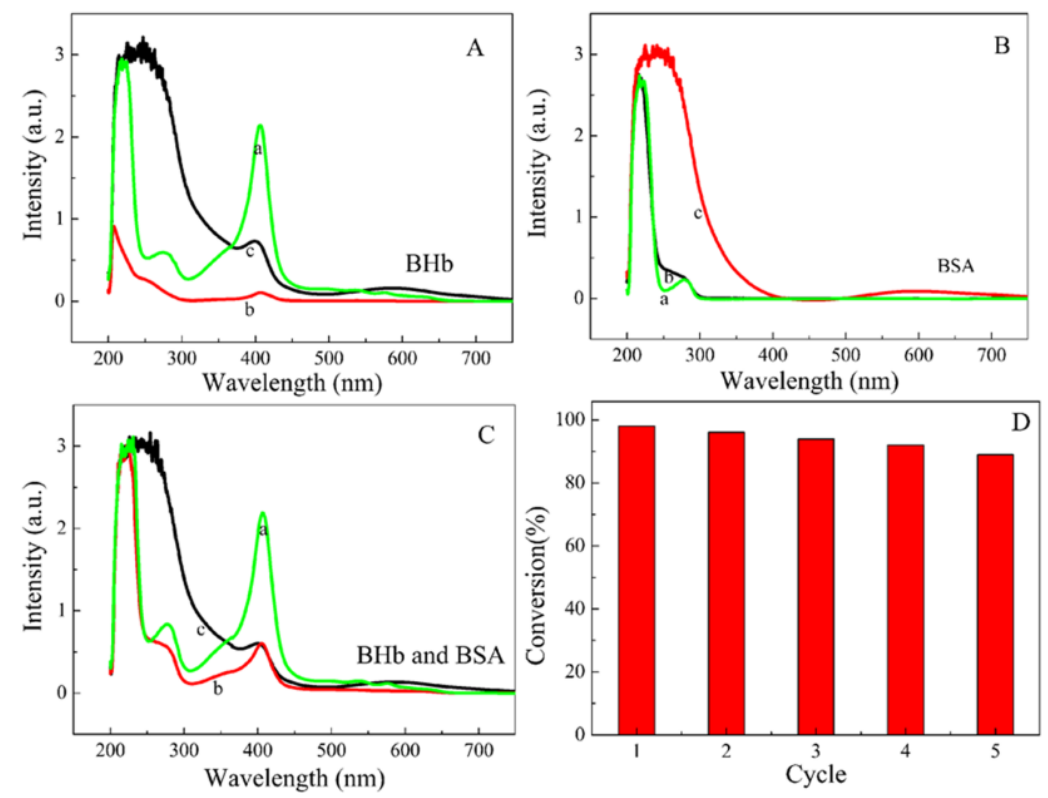

Fig. 8 Curve a is the UV-vis spectrum of $0.4 \mathrm{mg} \mathrm{mL}^{-1}$ of the $\mathrm{BHb}(\mathrm{A}), \mathrm{BSA}(\mathrm{B}) \mathrm{BHb}$ and BSA mixture (C) before adsorption by $\mathrm{CNTs} / \mathrm{Fe}_{3} \mathrm{O}_{4} @ \mathrm{CuSilicate}$. Curve $\mathrm{b}$ is the UV-vis spectrum of supernatant of BHb (A), BSA (B), BHb and BSA mixture (C) after adsorbed by $\mathrm{CNTs} / \mathrm{Fe}_{3} \mathrm{O}_{4} @ \mathrm{CuSilicate}$. Curve $\mathrm{c}$ is the UV-vis spectrum of desorption solution of the adsorbed protein by $\mathrm{CNTs} / \mathrm{Fe}_{3} \mathrm{O}_{4} @ \mathrm{CuSilicate}$ in $\mathrm{BHb}(\mathrm{A})$, BSA (B), BHb and BSA mixture (C) using concentration of $0.2 \mathrm{~g} \mathrm{~mL}^{-1}$ of dimethyl imidazole solution as the eluent. $\mathrm{D}$ is the recyclability of the $\mathrm{CNTs} / \mathrm{Fe}_{3} \mathrm{O}_{4} @$ CuSilicate as the absorbent for BHb.

In addition, The single protein $\mathrm{BHb}\left(0.4 \mathrm{mg} \mathrm{mL}^{-1}\right)$ and BSA $\left(0.4 \mathrm{mg} \mathrm{mL}^{-1}\right)$, a binary protein mixture containing $0.4 \mathrm{mg} \mathrm{mL}^{-1} \mathrm{BHb}$ and BSA respectively were incubated with $\mathrm{CNTs} / \mathrm{Fe}_{3} \mathrm{O}_{4} @ \mathrm{CuSilicate}$ composites for $6 \mathrm{~h}$ at room temperature. The adsorbed proteins could be eluted by dimethyl imidazole solution $\left(0.2 \mathrm{~g} \mathrm{~mL}^{-1}\right)$. The protein concentration in the supernatant was analyzed using a UV-vis spectrophotometer at 280 and $406 \mathrm{~nm}$ for BSA and BHb respectively. As shown in Fig. 8, the absorption intensity of $\mathrm{BHb}$ at $406 \mathrm{~nm}$ revealed the efficient removal of $\mathrm{BHb}$ from the single BHb solution, and the binary $\mathrm{BHb}$ and BSA solution (Fig. $8 \mathrm{~A}(\mathrm{~b}), \mathrm{C}(\mathrm{b}))$, while the adsorption intensity of BSA exhibits a negligible decrease at $280 \mathrm{~nm}$. Compared with 
the absorption spectra of the single $\mathrm{BHb}$ and of binary protein solutions $(\mathrm{BHb}$ and BSA), an interesting phenomenon was observed. When BSA is considered as a competitive protein, the amount of adsorbed $\mathrm{BHb}$ is lower than that of single solution. This is mainly attributed to the interaction between $\mathrm{BHb}$ and BSA is relatively stronger than that of without competitive protein. The interaction between proteins has the negative effect on the adsorption of the $\mathrm{BHb}$. The difference on the adsorption capacity of $\mathrm{CNTs} / \mathrm{Fe}_{3} \mathrm{O}_{4} @ \mathrm{CuSilicate}$ composites towards $\mathrm{BHb}$ and $\mathrm{BSA}$ may be ascribed to the different histidine residues in the proteins. It is well known that the number of accessible histidine residues on $\mathrm{BHb}$ is 24 , whereas there are only 2 histidine residues on the surface of BSA. The captured $\mathrm{BHb}$ on the $\mathrm{CNTs} / \mathrm{Fe}_{3} \mathrm{O}_{4} @$ CuSilicate composites was released by the treatment of the composites with dimethyl imidazole solution $\left(0.2 \mathrm{~g} \mathrm{~mL}^{-1}\right)$. Because the dimethyl imidazole has a strong metal chelating interaction with $\mathrm{Cu}^{2+}$, it resulted in the release of $\mathrm{BHb}$ protein from the $\mathrm{CNTs} / \mathrm{Fe}_{3} \mathrm{O}_{4} @ \mathrm{CuSilicate}$ composites. After complete desorption of His-tagged proteins, the $\mathrm{CNTs} / \mathrm{Fe}_{3} \mathrm{O}_{4} @ \mathrm{CuSilicate}$ composites could be reused after sonication in buffer to release the excess adsorbed dimethyl imidazole. The time of sonication was very important to improve the adsorption activity. Thus, the 30 minutes was selected for releasing the excess adsorbed dimethyl imidazole. Here, the $\mathrm{CNTs} / \mathrm{Fe}_{3} \mathrm{O}_{4} @ \mathrm{CuSilicate}$ composites were reused up to five times through the centrifugal separation and subsequent release of the captured protein. As shown in Fig. 8D, it reveals the reduction of $\mathrm{BHb}$ drops slightly after each cycle, and it decreased gradually in subsequent runs to $89 \%$ at run 5 , indicating that the $\mathrm{CNTs} / \mathrm{Fe}_{3} \mathrm{O}_{4} @ \mathrm{CuSilicate}$ composites have excellent separation efficiency.

In order to further demonstrate the specific adsorption of $\mathrm{CNTs} / \mathrm{Fe}_{3} \mathrm{O}_{4} @ \mathrm{CuSilicate}$ composites to $\mathrm{BHb}$ and explore its application in the real samples (human blood), the mixtures of binary proteins $\mathrm{BHb}$ and BSA solution, diluted human blood were carried out by contacting $\mathrm{CNTs} / \mathrm{Fe}_{3} \mathrm{O}_{4} @ \mathrm{CuSilicate}$ composites. The supernatant solution and the desorption solution of $\mathrm{CNTs} / \mathrm{Fe}_{3} \mathrm{O}_{4} @ \mathrm{CuSilicate}$ composites from the adsorbent by 
dimethyl imidazole solution $\left(0.2 \mathrm{~g} \mathrm{~mL}^{-1}\right)$ were analyzed by sodium dodecyl sulfate polyacrylamide gel electrophoresis (SDS-PAGE). From the SDS-PAGE analysis (Fig. 9), it could be seen that the BHb band obviously faded while the BSA band nearly remained as original (lane 3) after treatment with the $\mathrm{CNTs} / \mathrm{Fe}_{3} \mathrm{O}_{4} @ \mathrm{CuSilicate}$ composites. The eluted solution from $\mathrm{CNTs} / \mathrm{Fe}_{3} \mathrm{O}_{4} @ \mathrm{CuSilicate}$ composites showed the $\mathrm{BHb}$, BSA band, which demonstrated the specific absorption on his-tagged proteins (lane 4). This further demonstrated that most of the protein adsorbed by $\mathrm{CNTs} / \mathrm{Fe}_{3} \mathrm{O}_{4} @ \mathrm{CuSilicate}$ composites was $\mathrm{BHb}$. Compared with that of the binary proteins mixture of $\mathrm{BHb}$ and $\mathrm{BSA}$, the two bands between 10-fold human whole blood solution and adsorbed solution by the $\mathrm{CNTs} / \mathrm{Fe}_{3} \mathrm{O}_{4} @ \mathrm{CuSilicate}$ composites is not quite obvious, the reason can be explained as follows: The human blood consists of many kinds of proteins including $\mathrm{HSA}, \mathrm{HHb}$, the proteins interaction among $\mathrm{HHb}$, HSA and other proteins in human blood will lead to the loss of the capacity adsorption on $\mathrm{HHb}$, which is also verified by our previous work[30]. Consequently, the adsorbed solution by treatment with the $\mathrm{CNTs} / \mathrm{Fe}_{3} \mathrm{O}_{4} @ \mathrm{CuSilicate}$ composites was almost the same as that of the original diluted human blood band. However, it can still be observed that the $\mathrm{HHb}$ and HSA proteins were existed in the eluted solution from the adsorbed $\mathrm{CNTs} / \mathrm{Fe}_{3} \mathrm{O}_{4} @ \mathrm{CuSilicate}$ composites. This fully indicates that the $\mathrm{CNTs} / \mathrm{Fe}_{3} \mathrm{O}_{4} @ \mathrm{CuSilicate}$ composites can effectively remove the abundant proteins(HHb and $\mathrm{HSA})$ in the real biological samples, which seriously hamper the detection of less abundant proteins that are often markers of diseases.

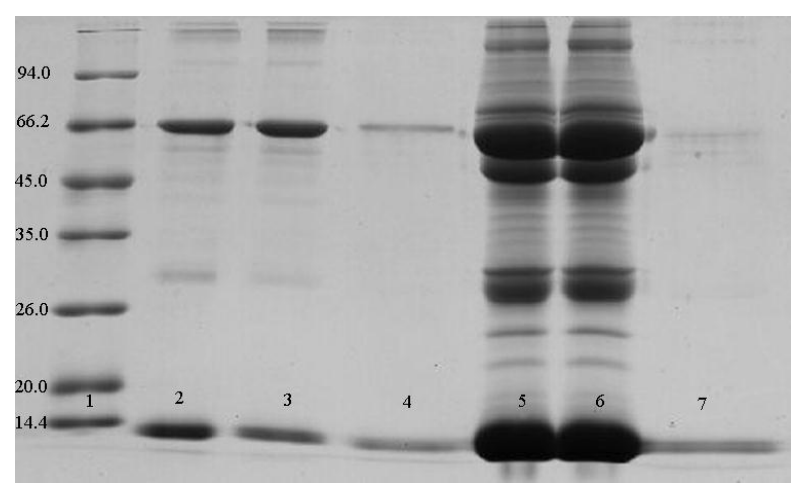


Fig. 9 SDS-PAGE analysis of adsorption by $\mathrm{CNTs} / \mathrm{Fe}_{3} \mathrm{O}_{4} @ \mathrm{CuSilicate}$ composites from solution. Lane 1, marker; lane 2, $0.6 \mathrm{mg} \mathrm{ml}^{-1}$ of BHb and BSA binary solution; lane 3, remaining $\mathrm{BHb}$ and $\mathrm{BSA}$ solution after adsorption by CNTs $/ \mathrm{Fe}_{3} \mathrm{O}_{4} @ \mathrm{CuSilicate}$ composites; lane 4, the eluted BHb and BSA mixture by 0.2 $\mathrm{g} \mathrm{ml}^{-1}$ dimethyl imidazole solution; lane 5, 10-fold human whole blood; lane 6, remaining human whole blood solution after adsorption by $\mathrm{CNTs} / \mathrm{Fe}_{3} \mathrm{O}_{4} @ \mathrm{CuSilicate}$ composites; lane 7 , the eluted 10 -fold human whole blood by $0.2 \mathrm{~g} \mathrm{ml}^{-1}$ dimethyl imidazole solution

\section{Conclusions}

We have demonstrated a facile method for the synthesis of hierarchical magnetic composites with copper silicate shells and superparamagnetic $\mathrm{CNTs} / \mathrm{Fe}_{3} \mathrm{O}_{4}$ cores. Due to the high alterability of the $\mathrm{SiO}_{2}$ coating thickness, the thickness of CuSilicate nanoneedles can be technically designed. In virtue of the unique structural features, these $\mathrm{CNTs} / \mathrm{Fe}_{3} \mathrm{O}_{4} @ \mathrm{CuSilicate}$ composites exhibit high adsorptive property with excellent cycling stability, which suggests their potential application in protein adsorption. Morover, the $\mathrm{CNTs} / \mathrm{Fe}_{3} \mathrm{O}_{4} @ \mathrm{CuSilicate}$ composites was successfully employed to selectively bind and removal abundant proteins ( $\mathrm{HHb}, \mathrm{HSA}$ ) from human blood samples. The good results demonstrated their potential in separation of His-rich proteins from biological samples. Meanwhile it has also high potential in other fields such as supports for noble metal catalysts and supercapacitors. Additionally, this strategy can be extended as a general method to prepare other magnetic metal silicate nanocables.

\section{Acknowledgements}

The authors are grateful to the financial support by the National Science Foundation of China (No 21305086). The Natural Science Foundation of Shanghai City (13ZR141830), Research Innovation Program of Shanghai Municipal Education Commission (14YZ138), the Special Scientific Foundation for Outstanding Young Teachers in Shanghai Higher Education Institutions (ZZGJD13016), Start-up 
Funding of Shanghai University of Engineering Science, and Shanghai University of Engineering Science Innovation Fund for Graduate Students

\section{References}

[1] (1) (a) J.Arnau, C.Lauritzen, G.E.Peterson, J.Pedersen, Protein Expression Purif. 48 (2006) 1-13. (b) G.Zhen, D.Falconnet, E.Kuennemann, J. Voros, N.D.Spencer, M. Textor, S.Zurcher, Protein Expression Purif. 48 (2006) 1-13. (c) J.E.Dyr, J.Suttnar, J. Chromatogr. B. 699 (1997) 383-401. (d) P.Mascagni, H.L.Ball, G. Bertolini, Anal. Chim. Acta. 352 (1997) 375-385.

[2] N. O. Fischer, C. D. Blanchette, B. A. Chromy, E. A. Kuhn, B. W. Segelke, M. Corzett, G. Bench, P. W. Mason , P. D. Hoeprich, Bioconjugate Chem. 20 (2009) $460-465$.

[3] R. Ahrends, S. Pieper, B. Neumann, C. Scheler, M. W. Linscheid, Anal. Chem. 81(2009) 2176-2184.

[4] (a) C.Xu, K.Xu, H.Gu, X.Zhong, Z. Guo, R. Zheng, X. Zhang, B. Xu, J. Am. Chem. Soc. 126 (2004) 3392-3393. (b) C. Xu, K.Xu, H. Gu, R.Zheng, H. Liu, X.Zhang, Z. Guo, B. Xu, J. Am. Chem. Soc. 126 (2004) 9938-9939.

[5] F.Xu, J.K.Geiger, G.L. Baker, M.L. Bruening, Langmuir 27 (2011) 3106-3112.

[6] (a) K.B.Lee, S. Park, C.A. Mirkin, Angew. Chem., Int. Ed. 43 (2004) 3048-3050.

(b) B.K.Oh, S. Park, J.K. Millstone, S.W. Lee, K.B. Lee, C.A. Mirkin, J. Am. Chem. Soc. 128 (2006) 11825-11829.

[7] I.S.Lee, N. Lee, J. Park, B.H. Kim, Y.W. Yi, T. Kim, T.K. Kim, I.H. Lee, S.R. Paik, T. Hyeon, J. Am. Chem. Soc. 128 (2006) 10658-10659.

[8] B.J.Kim, Y. Piao, N.Lee, Y. Il. Park, I.H. Lee, J.H. Lee, S.R. Paik, T. Hyeon, Adv. Mater. 22 (2010) 57-60.

[9] J. Qu, W. Li, C. Cao, X. Yin, L. Zhao, J. Bai, Z. Qin, W. Song, J. Mater. Chem. 22 (2012) $17222-17226$.

[10] Q. Fang, S. Xuan, W. Jiang, X . Gong, Adv Funct Mater. 21(2011) 1902-1909 
[11] Z. Liu, M. Li, X. Yang, M. Yin, J. Ren, X . Qu, Biomaterials32.(2011) $4683-4690$

[12] Y. Wang, G. Wang, Y. Xiao, Y. Yang, R. Tang, ACS Applied Materials \& Interfaces. 21 (2014) 1909-2

[13] R. Jin, Y. Yang, , Y. Xing, L. Chen, S. Song, R. Jin, ACS Nano. 8 (2014) 3664-3670.

[14] R. Jin, Y. Yang, Y. Xing, L. Chen, S. Song, Z. Shi, ChemPlusChem. 80 (2014) 544-548.

[15] R. Jin, Y. Yang, Y. Xing, L. Chen , S. Song, Chem. Commun. 50 (2014) $5447-5450$.

[16] C. Cao, F. Wei, J. Qu, W. Song, Chem. Eur. J. 19 (2013) 1558 - 1562.

[17] Z. Sun, Z. Liu, Y. Wang, B. Han, J. Du , J. Zhang, J. Mater. Chem. 15 (2005) 4497-4501.

[18] M. Zhang, P. Xia, L. Wang, J. Zheng, Y. Wang, J. Xu , L. Wang, RSC Adv. 4 (2014) 44423-44426.

[19] Y. Wang, G. Wang, H. Wang, W. Cai , L. Zhang, Chem. Commun. 48 (2008) 6555-6557.

[20] H. Chen, X. Lu, C. Deng, X. Yan, J. Phys. Chem. C. 113 (2009) 21068-21073.

[21] T. Zhu, B. Xia, L. Zhou, X. Lou, J. Mater. Chem. 22 (2012) 7851-7855.

[22] J. Liu, J. Cheng, R. Che, J. Xu, M. Liu, Z. Liu, ACS Appl. Mater. Interfaces. 5 (2013) 2503-2509.

[23] Y. Zhou, W. Jiang, S. Xuan, X. Gong, F. Ye, S. Wang, Q. Fang, J. Mater. Chem. B. 1 (2013) 1414-1420.

[24] B. Fei, B. Qian, Z. Yang, R. Wang, W. C. Liu, C. L. Mak , J. H. Xin, Carbon. 46 (2008) 1795-1797.

[25]_E. Nossol, A. Nossol, S. Guo, J. Zhang, X. Fang, A. Zarbin, A. Bond, J. Mater. Chem. C. 2 (2014) 870-878. 
[26] R. Guillet-Nicolas, J.-L. Bridot, Y. Seo, M.-A. Fortin , F. Kleitz, Adv. Funct. Mater. 21 (2011) 4653-4662.

[27] L. Tan, D. Chen, H. Liu, F. Tang, Adv. Mater. 22 (2010) 4885 -4889

[28] N. Zhang, X. Fu, Y.-J. Xu, J. Mater. Chem. 21 (2011) 8152 -8158.

[29] J. Liu, J. Cheng, R. Che, J. Xu, M. Liu, Z. Liu, Appl. Mater. Interfaces.5 ( 2013) 2503-2509.

[30] M. Zhang, Y. Wu, X. Feng, X. He, L. Chen , Y. Zhang, J. Mater. Chem. 20 (2010) 5835-5842 